Cahiers du MONDE RUSSE

\section{Cahiers du monde russe}

Russie - Empire russe - Union soviétique et États indépendants

\section{$57 / 1 \mid 2016$}

Terres, sols et peuples : expertise agricole et pouvoir (xixe - xxe siècles)

\title{
The Soviet Village Revisited
}

Household farming and the changing image of socialism in the late Soviet period

Le village soviétique revisité : exploitations agricoles familiales et évolution du socialisme à la fin de la période soviétique

\section{Katja Bruisch}

\section{OpenEdition}

\section{Journals}

Electronic version

URL: http://journals.openedition.org/monderusse/8332

DOI: $10.4000 /$ monderusse. 8332

ISSN: $1777-5388$

\section{Publisher}

Éditions de l'EHESS

\section{Printed version}

Date of publication: 1 January 2016

Number of pages: 81-100

ISBN: 978-2-7132-2540-6

ISSN: $1252-6576$

\section{Electronic reference}

Katja Bruisch, «The Soviet Village Revisited », Cahiers du monde russe [Online], 57/1 | 2016, Online since 01 January 2019, Connection on 21 April 2019. URL : http://journals.openedition.org/ monderusse/8332 ; DOI : 10.4000/monderusse.8332

\section{This text was automatically generated on 21 April 2019}

(C) École des hautes études en sciences sociales 


\section{The Soviet Village Revisited}

Household farming and the changing image of socialism in the late Soviet period

Le village soviétique revisité: exploitations agricoles familiales et évolution du socialisme à la fin de la période soviétique

Katja Bruisch

\section{EDITOR'S NOTE}

Translated from German by Bill Templer

1 Towards the end of perestroika, the promotion of cooperatives and family farming became increasingly accepted as means to overcome the lack of productivity and dynamism in Soviet agriculture. ${ }^{1}$ Allowing citizens to set up cooperatives and rent land, the Soviet government launched the establishment of a private farming sector. The 1991 Law on Peasant Farms (Zakon o krest'ianskikh (fermerskikh) khoziaistvakh), a reaction to the spontaneous foundation of private farms since the middle of the 1980s, created the legal basis for market-based household farming. The law was flanked by the Land Code, which marked the end of the Soviet state monopoly on land. Farmers could now become the legal owners of their fields. ${ }^{2}$ During the transition reforms of the 1990s, the household farm was embraced as a major area of agricultural politics. The preference for large-scale farming, a dominant feature of Soviet ideology since Stalin's turn to collectivisation, ceased to be the dominant frame of agricultural policy. ${ }^{3}$

2 Initially, perestroika was presented as an attempt to revive the spirit of the New Economic Policy (NEP) that had come to an end with Stalin's turn towards industrialisation and the coercive collectivisation of the village. A combination of market incentives, state intervention, independent cooperatives and central economic planning promised to fulfil Lenin's last testament. Economic and political reforms should help the Soviet Union overcome the condition of "stagnation" (zastoi) and enter a phase of "acceleration" (uskorenie). ${ }^{4}$ In this context, there was a return to the thinking of the 
economist Aleksandr V.Chaianov. In the late phase of perestroika, he was among the most frequently cited authorities to which reformers in favour of private farming and cooperatives referred. The reappraisal of the economist manifested itself in publications on his tragic biography, ${ }^{5}$ while at the same time leaving landmarks in the commemorative landscape of Moscow. Among these were a Chaianov street in the very centre of the city and a memorial plaque on the grounds of the Agricultural Timiriazev Academy where Chaianov had worked until his dismissal in the late 1920s. Nowadays, Russian surveys on the history of economic thought devote special sections to Chaianov, thus assigning him a solid place in the pantheon of Russian economists. ${ }^{6}$

3 The rediscovery of Chaianov is generally regarded as a result of the changed political and social atmosphere after Mikhail S. Gorbachev had become the head of the Communist Party in 1985. Indeed, the revitalisation of the public sphere during perestroika and the official admission that Soviet modernisation had claimed millions of lives opened the door to memorialising the economist, who had been executed during the Stalinist terror.? Yet, Chaianov's return also needs to be linked with the official image of the rural economy-and household farming in particular-prior to the beginning of glasnost' and perestroika. As will be shown in this article, in academic and political debates on private subsidiary farms (lichnye podsobnye khoziaistva), the socialist village took on new contours long before Gorbachev came to power. In the light of deepening rural crisis, household farming, which had previously been condemned as either a "petty-bourgeois" mode of production or an indicator of the incompleteness of Soviet socialism, was accepted as a component of socialist agriculture. Mirroring a new understanding of socialism in the Soviet Union, this paradigm shift was also an important precondition for the broad public response to Chaianov's rehabilitation and the rediscovery of his work in the period of perestroika. Yet in the end, the turn to family farming and agricultural cooperation remained a mainly intellectual and political phenomenon with barely any impact on the Russian agrarian order itself.

\section{Household farming in early Soviet agrarian discourse}

4 The turn to Chaianov's ideas in the late Soviet period followed a long tradition of thinking about agriculture that dated back to the pre-revolutionary period. In the late $19^{\text {th }}$ century, statisticians constructed the peasant household as a distinct social and economic unit. While before agrarian discourse had evolved around the paradigm of the village commune, it now focussed on the peasant family as the major agent in Imperial Russian agriculture. ${ }^{8}$ In this context, Chaianov developed a microeconomic model of the peasant household which provided a scientific foundation for the populist vision of a non-capitalist future for Russia. In keeping with the anti-capitalist thinking and identity of the intelligentsia, the economist believed that peasant households were free from the logic of capitalism. Instead of a desire for profit-making, peasants seemed to be motivated solely by the subsistence needs of their families. According to the "labour-consumer balance," Chaianov's major theoretical invention, peasants searched for an equilibrium between the consumption needs and the labour resources of the household. Given their renunciation of hired labour, the demographic composition of a peasant family was a key determinant of their farming activities. ${ }^{9}$

5 However, Chaianov did not imagine the peasant economy as stationary. In particular, well-functioning cooperatives would allow peasants to flexibly adjust their production to 
changing market conditions, while at the same time raising their own standard of living. A protagonist of the pre-revolutionary cooperative movement, ${ }^{10}$ the economist claimed that peasant agrarian structures and rural development were compatible. ${ }^{11}$ After the revolution, Chaianov developed a theory of cooperatives which reflected his idea that peasant households should ideally combine the advantages of small-scale farming with those of large-scale economic operations. Thus, it would be most efficient if households handed over those tasks, where they were inferior to larger economic units to cooperatives, while carrying on in segments in which small-scale operations had a clear advantage. In Chaianov's view, an agrarian order based on these "differential optimums" promised income increases for individual households as well as prospects for growth in the farming sector as a whole, opening up the opportunity for a more fundamental change of the rural order in the long run. The process of gradual "cooperative collectivisation" (kooperativnaia kollektivizatsiia), in the course of which peasant households would give up more and more of their initial activities, would modernise agriculture facilitating the introduction of advanced technology, scale economies and planning, without disbanding the principles of voluntary cooperation. ${ }^{12}$

During the 1920s, Chaianov combined his activity as a scholar with employment as an expert in the ranks of the People's Commissariat for Agriculture. Although his involvement in the agricultural decision-making of the Soviet state testified to the economist's respected reputation, his position was not undisputed. In Bolshevik discourse, the peasants served as the negative antipode of the proletariat. Seizing upon the stereotype of peasant backwardness widespread already before the revolution, ${ }^{13}$ Soviet elites conceived the mission to educate the peasants and transform them into conscious proletarians. ${ }^{14}$ While during the years of the New Economic Policy it seemed that peasant-based agriculture and Soviet rule were compatible, the turn towards accelerated industrialisation and collectivisation in the late 1920s proved the opposite. Chaianov, who had been repeatedly defamed as a "peasantist" since the Bolshevik takeover, was now increasingly attacked for upholding anti-Soviet positions. Charged with being an alleged member of a conspiratorial organisation, he was arrested in 1930 together with other leading agrarian experts. In 1934 the economist was banned to Kazakhstan, where in 1937 he was arrested again and subsequently executed. ${ }^{15}$

7 Aimed at the integration of the rural economy into the hierarchies of the centrally planned command economy, collectivisation targeted the peasant household as a concrete economic and social unit as well as an analytical category. In the view of the Stalinist elite, a socialist agrarian economy was bound up with collective enterprises; it did not take place within peasant households. As kolkhozniki, the rural population was to participate in the construction of socialism, transforming the village into an arena of modernity. ${ }^{16}$ After the turn toward collectivisation, Soviet agrarian economics focused on technical questions of collective and state farms, while the influential theoreticians of the peasant economy, whose works had shaped the agrarian debate during the previous decades, lost their professional authority and their social prestige. ${ }^{17}$ As a result, the names of Chaianov and his close colleagues vanished from public and academic discourse. Nikolai P. Makarov (1886-1980), a close colleague and friend of Chaianov-who unlike many others survived the terror and in the 1960s became active again as an agrarian economist-adhered to the convention of public silence that surrounded Chaianov and others. Makarov used the ideal-typical divide of Soviet agriculture into collective and 
state farms as an analytical framework for his later works. ${ }^{18}$ In the mid-1960s, he even consciously refrained from publicly mentioning the names of his former colleagues. ${ }^{19}$

Other than Makarov, whose personal and professional biography had been strongly affected by the marginalisation of agricultural economists during the Stalinist period, a new cohort of Soviet academics transmitted the intellectual heritage of the 1920s. ${ }^{20}$ Historian Viktor P. Danilov (1925-2004), one of the first critics of the collectivisation, reintroduced Chainov's ideas in academic literature. In an exhaustive study published in 1977 of the Soviet village prior to the collectivisation, he insisted upon a critical examination of Chaianov's theory of the peasant economy, pointing to the rising interest in the economist among Western scholars. ${ }^{21}$ Showing that both demographic and economic factors had impacted upon the development of peasant farms before the onset of collectivisation, Danilov attributed some limited explanatory power to Chaianov's theory, albeit without challenging the official rejection of the economist's ideas. ${ }^{22}$ The history of economic thought likewise served to maintain the memory of intellectual traditions that had been cut off during the Stalinist period. From the late 1970s, Nadezhda K. Figurovskaia (1930-2012), a member of the Institute of Economics of the Soviet Academy of Sciences, published extensively on agrarian problems in the economic writings of the NEP and the early Stalinist period. ${ }^{23}$ Avoiding a clear affirmation of Chaianov's ideas, Danilov and Figurovskaia applied the common distinction between "socialist" and "bourgeois" economists, presenting Chaianov's ideas as an example of a non-socialist strand in early Soviet economic thought. After the rehabilitation of Chaianov, both scholars would be intensely involved in the rediscovery of the economist. 24

\section{Household farming and the eschatology of socialist progress}

9 While it was possible to remember Chaianov as a protagonist of "bourgeois" economic science, social scientists and economists who studied the Soviet village after the end of Stalinism avoided the application of concepts and terms which could have been directly associated with the economist. However, as family farming continued as an important element of Soviet agriculture, Chaianov's notion of the household whose members tried to balance consumption needs and labour resources kept shaping academic literature about the rural economy. In the early 1930s, as a response to the catastrophic situation in the villages after the collectivisation campaign, the Soviet leadership had made concessions to the rural population granting kolkhoz farmers the right to cultivate private plots and to keep cattle in so-called private subsidiary farms (lichnoe podsobnoe khoziaistvo). ${ }^{25}$ Initially conceived as a temporary compromise, this arrangement persisted until the end of the Soviet period. In the late 1950s, about one third of the Soviet agricultural production stemmed from private household farming. In 1990, that proportion was still some $24.2 \%{ }^{26}$ Like the Soviet economy as a whole, agriculture was based on an institutionalised compromise. ${ }^{27}$

10 Ideologically, the continuing importance of private subsidiary farming was anything but a trivial problem. In an ideal-type socialist village, there was no place for private plots. The considerable contribution of subsidiary farms to Soviet food production challenged the belief in the superiority of large-scale agriculture, which was a cornerstone of socialist 
economic doctrine. Moreover, the importance of household farming could be interpreted as a concrete danger for the Soviet order, as collective farms and private plots were both competing for the labour resources of the rural population. As long as subsidiary farms accounted for a significant share of their income, rural residents had a real incentive to minimise their time or labour effort in the collective and state farms ${ }^{28}$ The fact that many used their poorly paid jobs on collective farms to access resources that they needed on their private plots made those even more suspicious. ${ }^{29}$ Therefore, until the mid-1960s, the Soviet government undertook repeated attempts to restrict the extent of subsidiary farming. ${ }^{30}$

11 The tension between Marxist doctrine and pragmatic arrangements in economic practice made it difficult for Soviet social scientists to make sense of rural life. How could the village be described without questioning the success of socialist transformation in the countryside? Soviet ideology provided the necessary templates in order to render the phenomenon of subsidiary farming intelligible linguistically and in analytical terms. In accordance with the teleology of socialist progress, material facts that were not compatible with the ideal image of socialist society were declared to be pre-socialist "leftovers" (perezhitok). ${ }^{31}$ Imagining the present as a transitional moment on a path from a state of economic backwardness to socialism allowed for the possibility of interpreting the existence of non-socialist artefacts as indicators of ongoing change. ${ }^{32}$

When at the beginning of the 1950s, Soviet ethnographers under the leadership of Pavel I. Kushner (1889-1968) carried out an extensive study on kolkhoz life, they noted the fundamental importance of private plots for the budgets of rural families. In their view, the phenomenon was legitimate for two reasons: first, private household farms were purely "consumerist in character" (potrebitel'skii kharakter), and second, the contribution of "social" (i.e. linked to the kolkhoz) production to the income of an average kolkhoz family was constantly on the increase..$^{33}$ Although their analysis was reminiscent of some features of Chaianov's "labor-consumer balance," Kushner's team tried to avoid the impression that the demographic composition of rural families rather than collective agriculture was decisive for living standards in the countryside. ${ }^{34}$ They explained subsidiary agriculture within a comprehensive framework of social and economic change. Compared to the cities, as the authors stressed, the socialist transformation of the village was delayed..$^{35}$ Pointing to the transitional character of rural realities, they could thus ascribe a certain meaning to household farming without calling into question the Soviet model of progress.

Economists used a similar approach in order to address the important role played by private households in Soviet food production. Like the ethnologists that were involved in Kushner's famous expedition, they regarded private agriculture among collective farm workers as a form of production that would wither away with the further development of socialism. Vladimir G. Venzher (1899-1990), a staff member in the Institute of Economics of the Soviet Academy of Sciences and a proponent of market-economic principles in agrarian policy, inspired a group of later economists and sociologists to deal with household farming in the Soviet village. ${ }^{36}$ In a 1966 monograph, he admitted that private plots testified to the deficient level of production in the kolkhoz and that without them it would be impossible to secure sufficient food provision for the population. Venzher justified food production of private plots by stressing their orientation towards the consumption needs of the family members. However, it was crucial for him to emphasise that subsidiary plots could not be equated with the peasant farm (krest'ianskoe khoziaistvo) 
which had been in the centre of Chaianov's research. Brought about by the socialist transformation of the village, they would forfeit their compensatory function as soon as collective farms would produce sufficient foodstuffs. From that juncture on, "no one would want to operate a private plot in order to gain additional personal income." ${ }^{37}$ Committed to the socialist idea of economic development, the economist Vladislav A. Belianov (1933-2010) termed private household farming a "specific socialist transitional form of production." 38

While the eschatology of socialist progress allowed for discourse about private agriculture in the Soviet village, attempts to attribute private subsidiary plots an importance sui generis remained risky. Gelii I. Shmelev (1927-2004), a student of Venzher and like him a staff member at the Institute of Economics, found that academic interest in private household farming could stand in the way of an academic career. In his habilitation thesis finished in 1967, Shmelev argued that the potential production capacity of private subsidiary farms was being underestimated. In fact, private plots could substantially contribute and even raise their contribution to the country's food supply. ${ }^{39}$ Shmelev's opinion evidently shattered the foundations of Soviet economic doctrine. The economist was accused of espousing the notion that private subsidiary plots were superior to collective farms, a reproach similar to the one Chaianov had faced with regard to his notion of the "viability" (zhiznesposobnost') of peasant households under various economic regimes. Shmelev's work was kept under lock and key, while the official doctoral procedure continued, albeit with considerable delay. After he had defended his thesis twice (in 1969 and 1970), its final approval required another two years and the examination by various scientific commissions. ${ }^{40}$ Shmelev's experience was symptomatic : as long as the large-scale collective farm was lauded unchallenged as the ideal of socialist agriculture, scientists engaged in the empirical study of private farming laid themselves open to the charge of questioning the success of the Soviet path. While it was possible to embed subsidiary agriculture within a narrative of socialist progress, projections of a stable or even greater role of private plots in the future seemed to imply the inability of the country to further move towards socialism.

\section{Real-existing socialism in the Soviet countryside}

The framework for making sense of household farming in Soviet villages changed when in the 1970s, the Soviet leadership acknowledged the slow-moving pace of agrarian development as an urgent political problem. Under Leonid I. Brezhnev, gigantic sums were pumped into agriculture in order to modernise the farming infrastructure and stimulate yield growth. Additional measures to improve the country's agricultural performance included the increase of procurement and retail prices for agricultural goods, the payment of regular wages to collective farm workers and the issuing of internal passports for the rural population. Yet the attempts to change the trajectory of the rural economy proved unsuccessful. An uptick in agricultural production in the late 1960s was followed by a slowdown in the next decade. The Soviet Union became ever more dependent on imported foodstuffs, while rural-urban migration caused ongoing headaches for the government. ${ }^{41}$

Notwithstanding the clear preference of the Soviet leadership for industrial agriculture, growing awareness of crisis went hand in hand with a more conciliatory approach to household farming. After the 1936 Constitution had recognised private subsidiary farms 
as components of the collectivised village,$^{42}$ private plots were treated as a temporary phenomenon that served the singular purpose of securing the personal provision of the rural population. At the Central Committee Plenum in September 1953, it was still official doctrine that subsidiary farming would ultimately disappear. The resolution of the convention stated that kolkhoz members maintained private plots "to satisfy their consumption as long as these needs cannot yet be completely met by social production." ${ }^{43}$ However, the tone changed when Brezhnev came to power. After Khrushchev's attempts to limit private farming, the October plenary in 1964 decided to rescind the "arbitrary restrictions" on individual plots. ${ }^{44} \mathrm{~A}$ resolution by the Central Committee and the Council of Ministers in 1977 acknowledged the promotion of private subsidiary plots as an instrument of Soviet agrarian policy. The idea was to support the rural population by less strict regulations for keeping cattle and for the sale of privately produced foods as well as through the provision of cattle feed, credit and other means of production. ${ }^{45}$ Private agriculture was now seen as a means to secure higher incomes in the countryside and thus help the Soviet Union overcome the rural crisis.

17 In this context, the socialist village took on new contours. In 1978, Shmelev defined subsidiary private farming "as an essential component of socialist economy, which does justice to the socialist relations of production..." ${ }^{46}$ Shmelev was hardly alone in expressing this viewpoint. In the course of the 1970s, research on private subsidiary farming established itself as a branch of inquiry in the social sciences. Ever more rarely now were the private plots described as a defect of the Soviet rural order. ${ }^{47}$ Tatiana I. Zaslavskaia (1927-2013), like Shmelev and Belianov a student of Venzher and a leading authority in Soviet rural sociology, had paid attention to the phenomenon of household farming since the beginning of her academic career. ${ }^{48}$ In a collective study published by Zaslavskaia and her Novosibirsk colleague Rozalina V. Ryvkina in 1980, private plots were even called a "necessary condition for the development of the village." ${ }^{49}$ This expression reflected a fundamental new understanding of the socialist rural economy. Household farming no longer pointed up the incomplete nature of Soviet socialism. On the contrary : now it was its structural feature.

Beyond science and politics, the ideological reconciliation with the realities of the Soviet village was being attentively followed. In an influential Pravda article, published in 1977, Shmelev termed private subsidiary farming an "integrated component of socialist agriculture" (sostavnaia chast' sotsialisticheskogo sel'skogo khoziaistva). ${ }^{50}$ His readers appreciated that private production of food had finally received the recognition it rightfully deserved. Shmelev was asked to raise public awareness of the topic in the Soviet Union by means of newspaper articles and discussion on television, because "our kolkhozes and sovkhozes can provide the people with grain, sunflower oil, turnips and potatoes [...] but meat, milk, fruit [...] never ever." ${ }^{51}$ In responding to the economist, the residents of a village stressed that their private agricultural activity was valuable not only for the national economy. It also testified to their moral integrity :

We all engage in social labour. In our free time, we dedicate ourselves to planting vegetables. We live in the countryside and have learned that work in the field is a noble task. The work of the peasant is honourable (Trud krest'ianina pochoten). ${ }^{52}$

The reactions to Shmelev's article mirrored the revaluation of the countryside in the late Soviet period. In the context of demographic decline and the advance of industrial farming, rural regions became imaginary spaces where the bond to a largely forgotten, presumably better past had not yet been totally torn asunder. Authors of so-called 
"village prose" and proponents of the rising nature protection movement praised the rural regions as spaces of purity and authenticity. ${ }^{53}$ Attributing to household farming a non-economic value, social scientists contributed to the promotion of a positive image of the rural world as well. For sociologist Zemfira I. Kalugina, like Zaslavskaia and Ryvkina based in Novosibirsk, subsidiary farming was a "form in which the rural population expresses itself, part of recreational activities as well as an instrument for the education and professional orientation of the rural youth. ${ }^{54}$ From Kalugina's viewpoint, the private production of foodstuffs was thus a marker of a distinctive rural identity, whose strengthening would help revive Soviet villages.

The positive connotation of (imagined) rural life was in line with the pragmatic need of the government for increased agricultural production and a slowdown in rural-urban migration. A decree issued in January 1981 by the Central Committee and the Council of Ministers "On Additional Measures to Increase Production Levels in Private Subsidiary Farms" stated that it was necessary to promote household farming by means of credits, technical advice and improved conditions for production and marketing. At the same time, private agriculture should also be actively propagandised ${ }^{55}$ This resolution set the tone for the further debate. At a conference of agricultural scientists and economists held in the same year, A.I. Ievlev, deputy minister of agriculture, stressed that private subsidiary plots not only helped secure the supply of provisions for the country but also instilled a "love for nature and the soil" in the rural population. ${ }^{56}$ While being a Party Secretary for agriculture within the Central Committee, M.S. Gorbachev pointed to the non-economic function of private subsidiary farms as well. In an article published in 1982, he emphasised that apart from their economic importance, subsidiary farms played a "considerable social and educational role." ${ }^{57}$ At the beginning of the 1980s, the positive connotation of household farming had already become a commonplace in official Soviet rhetoric. Once ostracised as an indicator of incomplete socialist transformation, private subsidiary farms were now seen as a means for social inclusion.

The changing attitudes to private subsidiary farming in academic writing and late Soviet politics reflected growing concern about rural decline and a simultaneous shift in Soviet identity discourse. Although agrarian policy up until the end of the Soviet period continued to promote large-scale enterprises, the tone toward household farming became conciliatory. While private subsidiary farming had been treated before as a temporary compromise, it was now increasingly acknowledged as a permanent feature of the rural economy. The hesitant approval of the realities of rural life was a concomitant of the ideological shift that took place in the Brezhnev period. Now the guiding motif of Soviet self-understanding was not movement but stability. The description of their own time as "developed socialism" expanded and lengthened the present, postponing the advent of communism to an indefinite future. ${ }^{58}$ Ritual behaviour supplanted campaigns, while the revaluation and new coding of central concepts in Soviet discourse made ideology and real-life facts on the ground compatible. Economic and social phenomena that had no place in the utopianism of the revolutionary period and the actionism under Khrushchev were now integrated into a heterogeneous and less monolithic model of socialism. Under the changed conditions of official discourse, it thus proved possible to acknowledge the economic importance of household farming in present and future times and even to reinterpret it as a source of Soviet socialist identity. 


\section{Expert post-mortem : Reinventing Chaianov in the Soviet Union}

In the light of ever mounting migration from the villages and agricultural decline, M.S. Gorbachev, after being appointed General Secretary, gave priority to the revitalisation of rural regions. His agrarian politics included a reform of the bureaucratic apparatus, measures to improve social welfare and infrastructure in the countryside as well as attempts to create economic incentives to motivate the rural population to increase agricultural production..$^{59}$ This turn to the countryside involved a gradual revaluation of household farming. Already before becoming party head, Gorbachev had supported the idea that private subsidiary farms should enhance their activity by contracting with state and collective farms. Such an arrangement would help reconcile the interests of the state with those of the rural population..$^{60}$ Inspired by recent Hungarian agrarian reforms that had included concessions to cooperatives and market-based trade operations, after the beginning of perestroika Gorbachev increasingly thought of rural households as semi-independent producers. The enhancement of contract farming and finally the 1988 Law on Cooperatives granted some modicum of autonomy to private producers and made possible the setting up of independent cooperatives. ${ }^{61}$

The recognition of family farming and cooperatives as potential sources of agricultural growth provided the climate for the reappraisal of A.V. Chaianov. A decisive impulse in this respect came from agrarian scientist Aleksandr A. Nikonov, who during the perestroika years became a decisive link between academia and politics. Nikonov had not only been familiar with Chaianov's writings since the 1950s. He also was personally acquainted with Chaianov's friend and colleague N.P. Makarov, who was able to establish himself again as an agrarian economist in the $1960 \mathrm{~s} .{ }^{62} \mathrm{~A}$ former minister of agriculture in the Latvian Soviet Republic, Nikonov knew very well the functional logic of Soviet politics. At the same time, he was in personal contact with Gorbachev, since as director of the Stavropol Agricultural Institute he had been a member of the advisory committee for Gorbachev's doctoral thesis. ${ }^{63}$ In 1984, Nikonov took over the directorship of the All-Union Academy of Agricultural Sciences (VASKhNIL), a position of some political importance. After Gorbachev was elected General Secretary of the Communist Party, Nikonov made use of his personal connections, calling the attention of the Soviet leadership to the agricultural experts who had been silenced at the beginning of the 1930s. In the name of VASKhNIL, he sent a request in September 1986 to Gorbachev calling for the formal rehabilitation of Chaianov and his colleagues N.D. Kondrat'ev, A.N. Chelintsev and N.P. Makarov. ${ }^{64}$ Shortly thereafter, the General Secretary ordered the creation of a special commission including the KGB and the state procuracy that was put in charge of reviewing the case against the four economists. ${ }^{65}$ In June 1987, they were rehabilitated along with a number of other experts on economics and agriculture. ${ }^{66}$

The subsequent rediscovery of Chaianov by the Soviet academic public took place in a transnational setting. Since the mid-1960s, Chaianov's ideas had been integrated into the theoretical arsenal of Peasant Studies, which aimed at challenging dominating views about agrarian development. While classical modernisation theory predicted the disappearance of peasant households under capitalism, scholars in the new field pointed to the persistence of peasant household farming in large parts of the developing world.$^{67}$ Teodor 
Shanin, a former emigré from the Soviet Union and one of the most prominent representatives of the field of peasant studies in the West, was closely involved in the revaluation of Chainov in the Soviet Union. While Shanin was on a research trip in the Soviet Union in 1987, Nikonov asked him to deliver a lecture on the recently rehabilitated Chaianov. The event, initially planned for the senior staff of the Timiriazev Academy, marked the beginning of the public reappraisal and reappropriation of Chaianov. Several hundred persons attended the lecture, in which after more than five decades of public silence Shanin recalled the economist's tragic biography. ${ }^{68}$

Rising interest in the economist's intellectual legacy was reflected in numerous new editions of Chaianov's works. Scholars who had mentioned Chaianov in their publications already before his official rehabilitation, as well as economists who had contributed to integrating household farming into a less monolithic model of Soviet socialism, actively promoted the revival of the economist's ideas. A.A. Nikonov, G.I.Shmelev and V.A. Belianov, an economist who like Shmelev had been examining the role of private subsidiary plots in the Soviet village, were prominently involved in the publication of Chaianov's selected writings. ${ }^{69}$ G.I. Shmelev and N.K. Figurovskaia participated in a new edition of his theory of cooperation, published in 1991. Economist V.G. Venzher, who passed away shortly before the book came out, had been the official editorial reviewer of the edition..$^{70}$ Historian V.P. Danilov, a close friend of Shanin since the early 1980 s, when Shanin started regularly visiting the Soviet Union, ${ }^{71}$ was active in presenting Chaianov's cooperative theory to a Western audience..$^{72}$

Mirroring aspirations to reform Soviet socialism, the reappropriation of Chaianov's ideas linked up directly with the acknowledgement of household farming and the revalorisation of the village during the previous decade. At the same time, the theories and ideas which Chaianov had developed at the beginning of the $20^{\text {th }}$ century were compatible with the new turn in economic thinking that emerged during perestroika among scientists, politics and the public sphere. At a conference in 1988 on the occasion of the 100th anniversary of Chaianov's birth, A.A. Nikonov argued that Chaianov had not developed an alternative to socialism but rather an alternative version of socialism :

Only a person who associates socialism in a dogmatic and limited way with kolkhoz or sovkhoz farms, their strict centralism and their stereotypical character, only a person who is unfamiliar with the multitude of diverse forms of cooperative initiatives, can accuse Chaianov of having a non-socialist viewpoint. ${ }^{73}$

V.P. Danilov regarded Chaianov's work as an inspiration for projections of a socialist order which was different from the Soviet one, calling his theory of cooperation "a real alternative to collectivisation of the Stalinist variety." ${ }^{74}$ These statements exemplify the intellectual appeal of Chaianov among the supporters of perestroika. The writings of the economist advanced the conception of a model of socialism that integrated different forms of production and ownership, including household-based agricultural production and cooperatives. After his rehabilitation, Chaianov was thus considered a prophet of "socialism with a human face," whose realisation appeared on the political agenda after Gorbachev came to power. Scholars such as A.A. Nikonov, G.I. Shmelev and V.P. Danilov, who were consulted as experts during the perestroika years, ${ }^{75}$ provided the change in agricultural policy with the necessary authority. At the same time, the reappraisal of Chaianov served to testify to the credibility of the reformers themselves. By including Chaianov post mortem into the circle of agrarian experts, they could demonstrate the legitimacy of their own political program. 


\section{Conclusions} under Gorbachev and the revaluation of Soviet history. Made possible by the new conventions of public discourse during perestroika, the relevance which was ascribed to Chaianov's writings should also be understood as a result of the changed image of socialism that had shaped Soviet agrarian debate in the 1970s. While back then Soviet writers depicted the village as the last bastion of national Russian identity, social scientists and politicians increasingly admitted the fact that a substantial share in the country's agricultural production stemmed from private plots. Confronted with a slowdown in agricultural production and rural demographic decline, the Brezhnev administration, alongside investing in the public farm sector, took measures to support household farming. As Secretary of Agriculture in the Central Committee, Gorbachev continued this conciliatory approach to private production, approving the formation of family-based production units that cooperated with collective farms on a contractual basis. ${ }^{77}$ The teleological model of progress, which implied that household farming would necessarily wither away, had thus become obsolete already before the onset of perestroika.

The changing notion of socialism was indicative of a process that was not limited to the Soviet Union : namely the vanishing faith in the existence of a universal developmental path towards modernity. In the West, interest increased in household-based farming and Chaianov's theory of the peasant economy when due to persisting poverty in developing countries, modernisation theory lost its credibility. Not the overcoming of peasant farming but its promotion was now put on the agenda. ${ }^{78}$ In the Soviet Union, rising acknowledgement of household farming resulted from a comparable shift in the ideological system of coordinates : given the high share of the private sector in overall food production, household farming, which before had been perceived as a remnant of pre-socialist times or a side-effect of incomplete socialist transformation, was accepted as a feature of "real-existing socialism." The private production of food by rural households now came to be regarded as a feature of Soviet agriculture in the present and on into the future. From this perspective, the key role played by Teodor Shanin in the iconisation of Chaianov was symptomatic of a crisis in teleological approaches to progress on both sides 
of the Iron Curtain. The institutionalisation of Peasant Studies as krest'ianovedenie in post-Soviet Russia can be seen as a further proof of this. ${ }^{79}$

In the late perestroika years, the idea that household plots could potentially increase their production transitioned into suggestions to actively create a family farming sector within Soviet agriculture. The rural household was regarded as a point of departure for agricultural revival during Boris N. El'tsin's reforms as well. The privatisation of land and the transition to a market economy should help overcome the concentration of land in large-scale farms, while the expansion of the private farm sector based on the Law on Peasant Farms was expected to boost the standards of living among the rural population. Defining the peasant farm as an independent economic subject, which consisted of the members of a family able to work and other citizens that jointly run a farm, the law appealed to the notion of the rural household as the core of agricultural production, while at the same time legalizing production beyond personal needs. ${ }^{80}$

Yet market-oriented family farming has not become a dominant feature of Russia's agrarian structure. Contrary to the reformers' initial intents, post-Soviet Russian agriculture has faced the establishment of vertically integrated farms that often control all levels of the agricultural value-added chain, while labour-intense subsidiary farming is still widespread. ${ }^{81}$ Resistance by local administrations to turning land titles into actual landed property, lacking opportunities for the rural population to access credit and input markets, as well as non-transparent procedures of land entitlement prevented the establishment of a vibrant family farming sector. ${ }^{82}$ As a result, the enthusiastic return to Chaianov's vision of peasant farming and cooperation remained limited to academic debate and political rhetoric, with little impact on the outlook of the Russian countryside. The economic legacy of the Soviet rural order and the configurations of local power proved stronger than the belief in family farming as a catalyst for agricultural growth.

\section{NOTES}

1. I wish to thank three anonymous reviewers whose comments helped me sharpen the argument of this article.

2. Olesia Kirchik, "Zemel'naia reforma: 1990-2002 [The land reform: 1990-2002]," Otechestvennye zapiski, no. 1 (2004): http://www.strana-oz.ru/2004/1/ zemelnaya-reforma-1990-2002 (retrieved 1 October 2014).

3. Carol S. Leonard, Agrarian Reform in Russia : The Road from Serfdom (Cambridge : Cambridge University Press, 2011), 85-121.

4. Lars T. Lih, "Perestroika's Revival of NEP : A Contemporary Chronicle, 1985-1990," The NEP Era : Soviet Russia 1921-1928, 3 (2009) : 1-35 ; Robert W. Davies, Soviet History in the Gorbachev Revolution (Basingstoke : Macmillan, 1989), 27-46.

5. See among many others: V.N. Baliazin, Professor Aleksandr Chaianov, 1888-1937 (Moscow [hereafter M.] : Agropromizdat, 1990) ; V.V. Kabanov, “A.V.Chaianov," Voprosy istorii, no. 6 (1988) : 146-176 ; V.A. Chaianov, A.V. Chaianov : Chelovek-uchenyi-grazhdanin [A.V. Chaianov : person - scholar - citizen] (M. : Izdatel'stvo MSChA, 1998). 
6. See S.A. Bartenev, Istoriia èkonomicheskikh uchenii [The history of economic schools] (M. : Magistr, 2007), 263-266 ; V. Avtonomov, O. Anan'in and N. Makasheva, Istoriia èkonomicheskikh uchenii [The history of economic schools] (M.: INFRA-M, 2013), 440-47 ; Iu.Ia. Ol'sevich, "O spetsifike natsional'noi shkoly èkonomicheskoi mysli v Rossii [On the specificities of the national school of economic thought in Russia]," in: L.I. Abalkin, ed., Ocherki istorii rossiiskoi èkonomicheskoi mysli [Outlines on the history of Russian economic thought] (M. : Nauka, 2003) : 47-49 ; I.B. Poliubina, "Chaianov Aleksandr Vasil'evich," in N.N.Dumnaia and O.V. Karamova, Istoriia èkonomicheskoi mysli v Rossii v litsakh : Slovar' spravochnik [The history of economic thought in Russia in portraits : A handbook] (M. : Knorus, 2007), 347-353.

7. See, for example, Davies, Soviet History, 31, 134 ; Eberhard Müller, "Blick zurück im Zorn ?! Bürgerkrieg, Kriegskommunismus und Neue Ökonomische Politik,” in Dietrich Geyer, ed., Die Umwertung der sowjetischen Geschichte (Göttingen : Vandenhoeck \& Ruprecht, 1991), 75-102.

8. David W. Darrow, "From Commune to Household: Statistics and the Social Construction of Chaianov's Theory of Peasant Economy," Comparative Studies in Society and History, 43, 4 (October 2001) : 788-818.

9. Chaianov expressed these ideas already in the late Imperial period. See Katja Bruisch, Als das Dorf noch Zukunft war: Agrarismus und Expertise zwischen Zarenreich und Sowjetunion (Cologne : Böhlau, 2014), 60-66. The first coherent version of his theory appeared in German : Alexander Tschajanow, Lehre von der bäuerlichen Wirtschaft: Versuch einer Theorie der Familienwirtschaft im Landbau (Berlin : Parey, 1923). An extended version was published in 1925 in the Soviet Union : A.V. Chaianov, Organizatsiia krest'ianskogo khoziaistva [The organisation of the peasant economy] (M. : Kooperativnoe Izdatel'stvo, 1925).

10. On the involvement of experts in the pre-revolutionary cooperative movement, see Ilya Gerasimov, Modernism and Public Reform in Late Imperial Russia: Rural Professionals and Self-Organization, 1905-30 (New York : Palgrave Macmillan, 2009).

11. A.V. Chaianov, Kratkii Kurs Kooperatsii : Lektsii, chitannye na staroobriadcheskikh kursakh v Moskve, 1913g. [Short course on Co-operatives] (M. : Drug zemli, 1915).

12. A.V. Chaianov, Osnovnye idei i formy organizatsii sel'skokhoziaistvennoi kooperatsii. Izdanie 2-e [Basic ideas and organisational forms of agricultural cooperatives] (M. : Knigosoiuz, 1927) ; A.V. Chaianov, Optimal'nye razmery sel'sko-khoziaistvennykh predpriiatii. 3-e izdanie [Optimal farm sizes] (M. : Novaia derevnia, 1928).

13. Yanni Kotsonis, Making Peasants Backward: Agricultural Cooperatives and the Agrarian Question in Russia, 1861-1914 (New York : St. Martin's Press, 1999).

14. Dietrich Beyrau, "Janus in Bastschuhen : Die Bauern in der russischen Revolution 1905-1917," Geschichte und Gesellschaft, 21, 4 (1995) : 585-603.

15. On the marginalisation of agrarian experts at the end of the NEP, see Bruisch, Als das Dorf noch Zukunft war, 238-257.

16. On the modernistic impetus underlying collectivisation, see most recently Jenny Leigh Smith, Works in Progress : Plans and Realities on Soviet Farms, 1930-1963 (New Haven : Yale University Press, 2014).

17. Susan Solomon Gross, The Soviet Agrarian Debate: A Controversy in Social Science, 1923-1929 (Boulder : Westview Press, 1977), 155-170.

18. N.P. Makarov, Ėkonomicheskie osnovy organizatsii proizvodstva v kolkhozakh i sovkhozakh [The economic foundations of the organisation of production in collective and state farms] (M. : Kolos, 1966).

19. Bruisch, Als das Dorf noch Zukunft war, 301-302.

20. Alessando Stanziani, “Čajanov, Kerblay et les šestidesjatniki : une histoire globale ?," Cahiers du Monde russe, 45, 3-4 (2004) : 385-406. 
21. V.P. Danilov, Sovetskaia dokolkhoznaia derevnia: Naselenie, zemlepol'zovanie, khoziaistvo [The Soviet village before collectivisation : Population, land-use, economy] (M. : Nauka, 1977), 6-7.

22. Danilov, Sovetskaia dokolkhoznaia derevnia, 222-264.

23. N.K. Figurovskaia, Agrarnye problemy v sovetskoi èkonomicheskoi literature 20-kh godov [Agrarian problems in the Soviet economic literature of the 1920s] (M.: Nauka, 1978); N.K. Figurovskaia, Razvitie agrarnoi teorii v SSSR konets 20-kh - 30-e gody [The development of agrarian theory in the USSR at the end of the 1920s and in the 1930s] (M. : Nauka, 1983).

24. See, for example, N.K. Figurovskaia and A.I. Glagolev, "A.V. Chaianov i ego teoriia semeinogo krest'ianskogo khoziaistva [A.V. Chaianov and his theory of the peasant family economy]," in A.V.Chaianov, Krest'ianskoe khoziaistvo: Izbrannye trudy [The peasant economy: Selected works] (M.: Ėkonomika, 1995), 26-51; V.P.Danilov, "Russkaia revoliutsiia v sud'be A.V.Chaianova [The Russian Revolution in the fate of A.V.Chaianov]," Krest'ianovedenie, 1 (1996) : 96-133.

25. Stephan Merl, Bauern unter Stalin: Die Formierung des sowjetischen Kolchossystems 1930-1941 (Berlin : Duncker \& Humboldt, 1990), 257-288.

26. Karl-Eugen Wädekin, Privatproduzenten in der sowjetischen Landwirtschaft (Cologne : Verlag Wissenschaft und Politik, 1967); Stefan Hedlund, Private Agriculture in the Soviet Union (London, New York : Routledge, 1989).

27. The coexistence of collective and private economic enterprises was a constant feature of the Soviet economy. In the first few decades after the Second World War, private subsidiary plots were an important source of income for rural and also urban households. Andrei Markevich, "Finding Additional Income : Subsidiary Agriculture in Soviet Urban Households, 1941-1964," in Donald Filtzer, Wendy Z. Goldman, Gijs Kessler and Simon Pirani, eds., A Dream Deferred : New Studies in Russian and Soviet Labour History (Bern: Peter Lang, 2008), 385-415. On the importance of private production and private commerce in the late phase of Stalinism, see Julie Hessler, "A Postwar Perestroika? Toward a History of Private Enterprise in the USSR," Slavic Review, 57, 3 (Autumn 1998) : 516-542.

28. Stefan Hedlund, Crisis in Soviet Agriculture (London : Croom Helm, 1984), 161-165.

29. Wädekin, Privatproduzenten, 115-158; Hedlund, Crisis in Soviet Agriculture, 105-107.

30. Merl, Bauern unter Stalin, 295-318; Hedlund, Private Agriculture, 18-24; D.N. Konyshev, "Gosudarstvennaia politika ogranicheniia lichnogo podsobnogo khoziaistva (konets 1950-kh nachalo 1960-kh gg.) [State politics toward the restriction of private subsidiary farming (end of the 1950s - early 1960s]," Rossiiskaia istoriia, no. 3 (2011) : 102-111.

31. Sergei Alymov, "Poniatie 'perezhitok' i sovetskie sotsial'nye nauki v 1950 - 1960-e gody [The concept of the "remnant" and the Soviet social sciences in the 1950s - 1960s]," Antropologicheskii forum, no. 16 (2012) : 261-287.

32. Maya Haber, "The Soviet Ethnographers as a Social Engineer : Socialist Realism and the Study of Rural Life, 1945-1958," The Soviet and Post-Soviet Review, 41 (2014) : 194-219.

33. Selo Viriatino $\mathrm{v}$ proshlom i nastoiashchem: Opyt ètnograficheskogo izucheniia russkoi kolkhoznoi derevni [The village of Viriatino in past and present: Ethnographical study of the Russian collectivized village] (M. : Izdatel'stvo Akademii Nauk SSSR, 1958), 162-177.

34. Haber, "The Soviet Ethnographers as a Social Engineer...," 218.

35. Selo Viriatino v proshlom i nastoiashchem, 5.

36. On V.G. Venzher, see T. Kuznetsova, "Vladimir Grigor'evich Venzher : uchenyi i ego vremia [Vladimir Grigor'evich Venzher : a scholar and his time]," Voprosy èkonomiki, no. 5 (2014) : 132-142.

37. V.G. Venzher, Kolkhoznyi stroi na sovremennom ètape [The collective regime in its current phase] (M. : Ėkonomika, 1966), 45. 
38. V.A. Belianov, Lichnoe podsobnoe khoziaistvo pri sotsializme [Private subsidiary farming under socialism] (M. : Ėkonomika, 1970), 6.

39. G.I. Shmelev, Ėkonomika lichnogo podsobnogo khoziaistva trudiashchikhsia pri sotsializme : Avtoreferat dissertatsii na soiskanie uchenoi stepeni doktora ékonomicheskikh nauk [The economy of the private subsidiary farms of the workers under socialism] (M. : Institut Ėkonomiki Akademii Nauk SSSR, 1968). In 1989, Swedish economist Stefan Hedlund would call Shmelev the "leading Soviet authority on the private sector." Hedlund, Private Agriculture, 16.

40. G.I. Shmelev, "Agrarnaia teoriia : Trudnyi poisk istiny [Agrarian theory : A difficult search for the truth]," in A.V.Petrikov, ed., Teoreticheskoe nasledie agrarnikov-èkonomistov 50-80-kh godov i sovremennaia reforma $v$ sel'skom khoziaistve : Liudi. Idei. Fakty [The theoretical legacy of agrarian economists of the 1950-1980s and the recent reform in agriculture: People, Ideas, Facts] (M. : Academiia, 2009), 175-181.

41. Leonard, Agrarian Reform in Russia, 77-79 ; Alec Nove, An Economic History of the USSR, 1917-1991. New and Final Edition (London : Penguin Books, 1992), 377-382.

42. Konstitutsiia Soiuza SSR i Konstitutsii Soiuznykh Respublik [The constitution of the USSR and the constitutions of its allied republics] (M. : Iuridicheskoe Izdatel'stvo NKIu SSSR 1938), 8.

43. "O merakh dal'neishego razvitiia sel'skogo khoziaistva SSSR. Postanovlenie Plenuma TsK KPSS, priniatoe 7 sentiabria 1953 g. po dokladu tov. N.S. Khrushcheva [On the means for the further development of agriculture in the USSR. Decree of the Plenum of the Central Committee issued on 7 September 1953, based on the speech of N.S. Khrushchev]," in Sbornik reshenii po sel 'skomu khoziaistvu [Collection of decisions on agriculture] (M.: Izdatel'stvo Sel 'skokhoziaistvennoi Literatury, 1963), 81.

44. "Postanovlenie TsK KPSS 27 oktiabria 1964 g. ob ustranenii neobosnovannykh ogranichenii lichnogo podsobnogo khoziaistva kolkhoznikov, rabochikh i sluzhashchich [Decree of the Central Committee of 27 October 1964 on the abolition of the unfounded restrictions of the private subsidiary farms of collective farm workers, workers and employees]," in Resheniia partii i pravitel'stva po khoziaistvennym voprosam, Tom 5 : 1962-1965 gody [Decisions of the party and the government on economic questions, vol. 5, 1926-1965] (M.: Izdatel'stvo Politicheskoi Literatury, 1968), 517.

45. "Postanovlenie TsK KPSS i Soveta Ministrov SSSR 14 sentiabria 1977 o lichnykh podsobnykh khoziaistvakh kolkhoznikov, rabochikh, sluzhashchikh i drugikh grazhdan v kollektivnom sadovodstve i ogorodnichstve [Decree of the Central Committee and the Council of Ministers of 14 September 1977 on the private subsidiary farms of collective farm workers, workers, employees and other workers in collective gardening and horticulture]," in Resheniia partii i pravitel'stva po khoziaistvennym voprosam, Tom 12 : Iiul' 1977 g. - mart 1979 g. [Decisions of the party..., vol. 12, July 1977 - March 1979] (M. : Izdatel'stvo Politicheskoi Literatury, 1979), 104-111. 46. G.I.Shmelev, Lichnoe podsobnoe khoziaistvo truzhenika sela [The private subsidiary economy of the rural worker] (M. : Profizdat, 1978), 14.

47. A.A. Kurakin "Sel'skoe khoziaizstvo SSSR glazami sovremennikov [The agriculture of the USSR as seen by contemporaries]," Ėkonomicheskaia sotsiologiia, no. 7, 2 (2006) : 95-97.

48. T.I. Zaslavskaia, Izbrannye proizvedeniia: Sotsial'naia i èkonomicheskaia sotsiologiia [Selected writings : Social and economic sociology] (M. : Ėkonomika, 2007), 80-96.

49. T.I. Zaslavskaia and R.V. Ryvkina, Metodologiia i metodika sistemnogo izucheniia sovetskoi derevni [Methodology and method for a systemic study of the Soviet village] (Novosibirsk: Nauka, 1980), 138.

50. G. Shmelev, "O lichnom podsobnom khoziaistve [On the private subsidiary farm]," Pravda, 10 September (1977) : 3 .

51. RGAĖ (Rossiiskii Gosudarstvennyi Arkhiv Ėkonomiki), f. 1027 : private collection G.I. Shmelev, op. 1, d. $80,1.2$.

52. RGAÉ, f. 1027, op. 1, d. 80, 1. 12. 
53. Kathleen F. Parthé, Russian Village Prose : The Radiant Past (Princeton : Princeton University Press, 1992); Klaus Gestwa, “Ökologischer Notstand und sozialer Protest," Archiv für Sozialgeschichte, 43 (2003) : 349-383, here 373-375.

54. Z.I. Kalugina, "Politika sovetskogo gosudarstva $\mathrm{v}$ otnoshenii lichnogo podsobnogo khoziaistva : kharakteristika i sotsial'nye rezul'taty [The politics of the Soviet state toward private subsidiary farming: characteristics and social results]," in L.A. Khakhulina, ed., Sovremennoe razvitie sibirskogo sela: Opyt sotsiologicheskogo izucheniia. Sbornik nauchnykh trudov [The recent development of the Siberian village: Toward a sociological study] (Novosibirsk : Institut èkonomiki i organizatsii promyshlennogo proizvodstva, 1983), 96.

55. "Postanovlenie TsK KPSS i Soveta Ministrov SSSR 8 ianvaria 1981 g. o dopolnitel'nykh merakh po uvelicheniiu proizvodstva sel'skokhoziaistvennoi produktsii $\mathrm{v}$ lichnykh podsobnykh khoziaistvakh grazhdan [Decree of the Central Commitee and the Council of Ministers of 8 January 1983 on additional means for the increasing agricultural production on private subsidiary farms of the citizens]," in Resheniia partii i pravitel'stva po khoziaistvennym voprosam, Tom 13 : Aprel' 1979 g. - mart 1981 g. [Decisions of the party... vol. 13, April 1979 March 1981] (M. : Izdatel'stvo Politicheskoi Literatury, 1981), 544.

56. A.I. Ievlev, "Dopolnitel'nyi istochnik prodovol'stviia [An additional source of food]," in Lichnoe podsobnoe khoziaistvo $\mathrm{v}$ sisteme sotsialisticheskogo sel'skogo khoziaistva: Materialy Vsesoiuznogo nauchno-prakticheskogo soveshchaniia, 6-8 aprelia $1981 \mathrm{~g}$. [The private subsidiary farm in the system of socialist agriculture] (M. : Institut èkonomiki mirovoi sotsialisticheskoi sistemy, 1982) : 4-10, here p. 5.

57. M.S. Gorbachev, "Prodovol'stvennaia programma i zadachi ee realizatsii [The food program and the tasks for its realisation]," in idem, Izbrannye rechi i stat'i, Tom 1 [Selected speeches and articles, vol. 1] (M. : Izdatel'stvo Politicheskoi Literatury, 1987) : 302-320, here 306.

58. Stefan Plaggenborg, "Verstetigte Gegenwart : Über das Zeitverständnis im real existierenden Sozialismus," in Christiane Brenner and Martin Schulze Wessel, eds., Zukunftsvorstellungen und staatliche Planung im Sozialismus: Die Tschechoslowakei im ostmitteleuropäischen Kontext 1945-1989 (Munich : Oldenbourg 2010), 19-32 ; Boris Belge and Martin Deuerlein, "Einführung : Ein goldenes Zeitalter der Stagnation? Neue Perspektiven auf die Brežnev-Ära," in idem, eds., Ein goldenes Zeitalter der Stagnation? Neue Perspektiven auf die Brežnev-Ära (Tübingen : Mohr Siebeck, 2014), 1-33, here 10.

59. Judith Pallot, "Rural Depopulation and the Restoration of the Russian Village under Gorbachev," Soviet Studies, 42, 4 (Oct. 1990) : 655-674 ; Leonard, Agrarian Reform in Russia, 80-81. 60. M.S. Gorbachev, "XXVI s-ezd KPSS i agrarnaia politika partii : Iz doklada na Vsesoiuznom seminare-soveshchanii ideologicheskikh rabotnikov v Moskve 21 aprelia 1981 goda [The 26th congress of the Communist Party and the agrarian politics of the party: From the speech at the All-Union seminar of ideological workers in Moscow, 21 April 1981]," in idem, Izbrannye rechi i stat'i, 277.

61. Archie Brown, The Gorbachev Factor (Oxford : Oxford University Press 1996), 142-154.

62. A.A. Nikonov, Istoricheskii put' VASKhNIL i ee vklad v agrarnuiu nauku [The historical pathway of VASKhNIL and its contribution to the agricultural sciences] (M.: Éntsiklopediia rossiiskikh dereven, 1993), 13.

63. Brown, The Gorbachev Factor, 43. The close cooperation between Gorbachev and Nikonov is covered in greater detail by Olessia Kirchik in this issue.

64. RGAĖ, f. 785 : private collection Aleksandr Aleksandrovich Nikonov, op. 1, d. 156, 1. 8-12.

65. A.N. Artizov et al, eds., Reabilitatsiia : Kak èto bylo. Dok. prezidiuma TsK KPSS i dr. materialy, Tom 3 [Rehabilitation: How it was. Documents of the Presidium of the Central Committee of the Communist Party and other materials, vol. 3] (M. : Mezhdunarodnyi Fond "Demokratiia," 2004), 10.

66. Davies, Soviet History, 133-134. 
67. Teodor Shanin, ed., Peasants and Peasant Societies (Hardmondsworth : Penguin Books, 1971). For an exhaustive overview on the field, see Henry Bernstein and Terence J. Byres, "From Peasant Studies to Agrarian Change," Journal of Agrarian Change, 1, 1 (2001) : 1-56.

68. Teodor Shanin, “Chayanov's Treble Death and Tenuous Resurrection: An Essay about U nderstanding, about Roots of Plausibility and about Rural Russia," The Journal of Peasant Studies, 36, 1 (January 2009), 83-101 ; Davies, Soviet History, 31-32.

69. A.V.Chaianov, Krest'ianskoe khoziaistvo : Izbrannye trudy [The peasant economy : Selected works] (M. : Ėkonomika, 1989).

70. A.V. Chaianov, Osnovnye idei i formy organizatsii sel'skokhoziaistvennoi kooperatsii [Basic ideas and organisational forms of agricultural cooperatives] (M. : Nauka, 1991).

71. "Agrarnyi seminar pamiati Viktora Petrovicha Danilova 4-5 marta 2005 g. : Stenogramma vospominanii o Viktore Petroviche [The agrarian seminar in the memory of Viktor Petrovich Danilov 4-5 March 2005 : Stenograph of memories about Viktor Petrovich]," Krest'ianovedenie, 5 (2005) : 38-63.

72. A.V. Chayanov, The Theory of Peasant Co-operatives, translated by David Wedgwood Benn, introduction by Viktor Danilov (Columbus : Ohio State University Press, 1991).

73. A.A. Nikonov, "Nauchnoe nasledie A.V. Chaianova i sovremennost' [The academic heritage of A.V. Chaianov and the present time]," Vestnik sel'skokhoziaistvennoi nauki, no. 7 (1988) : 43-53, here 46.

74. V.P. Danilov, "Introduction," in Chayanov, The Theory of Peasant Co-operatives, xi-xxxiii, here xxxiii.

75. V.P. Danilov, "Iz istorii perestroiki : Perezhivaniia shestidesiatnika-krest'ianoveda [From the history of the perestroika: Experiences of a shestidesiatnik-krest'ianoved]," Otechestvennye zapiski no. 1 (2004) : Erreur! Référence de lien hypertexte non valide. (retrieved : 8 November 2014).

76. Marc Junge, Bucharins Rehabilitierung: Historisches Gedächtnis in der Sowjetunion 1953 1991 (Berlin : Basisdruck 1999).

77. Brown, The Gorbachev Factor, 45 ; Nove, An Economic History of the USSR, 382.

78. Eric Vanhaute, "Peasants, Peasantries and (De)Peasantization in the Capitalist World-System," in Salvatore Babones and Christopher Chase-Dunn, eds., Routledge Handbook of World-Systems Analysis (Oxon : Routledge, 2012) : 313-321 ; Jonathan Harwood, Europe's Green Revolution and Others Since: The Rise and Fall of Peasant-Friendly Plant Breeding (Oxon: Routledge, 2012).

79. The establishment of the discipline in post-Soviet Russia was driven mainly by Teodor Shanin and V.P. Danilov. On the development of the field, see T. Shanin, A. Nikulin and V. Danilov, eds., Refleksivnoe krest'ianovedenie: Desiatiletie issledovanii sel'skoi Rossii [Reflexive peasant studies : A decade of studying rural Russia] (M. : ROSSPÉN, 2002).

80. "Zakon RSFSR ot 22.11.1990 N 348-1 'O krest'ianskom (fermerskom) khoziaistve' [The Law of the RSFSR of 22 November 1990 "On the peasant farm"]," Vedomosti SND i VS RSFSR, 26 (1990) : 324.

81. Stephen Wegren, "Land Reform in Russia : What Went Wrong?," Post-Soviet Affairs, 28, 2 (2008) : 121-148; Oane Visser, Natalia Mamonova and Max Spoor, "Oligarchs, megafarms and land reserves : understanding land grabbing in Russia" The Journal of Peasant Studies, 39, 3-4 (2012) : 899-931.

82. Jessica Allina-Pisano, The Post-Soviet Potemkin Village : Politics and Property Rights in the Black Earth (Cambridge : Cambridge University Press, 2008). 


\section{ABSTRACTS}

The recognition of family farms and agricultural cooperatives as catalysts for agricultural recovery during the perestroika years went along with the rediscovery of the world-famous theoretician of the peasant farm Aleksandr V. Chaianov. The economist's rehabilitation resulted from the changing conventions of public discourse towards the end of the Soviet era. Yet, Chaianov's return needs to be linked also with the official image of the rural economy in the preceding decade when in academic and political debates on private subsidiary farms the socialist village took on new contours. Household farming which had previously been condemned as either a 'petty-bourgeois' mode of production or an indicator of the incomplete transition to socialism, was accepted as a component of socialist agriculture. Mirroring a new understanding of socialism, this paradigm shift was an important precondition for the broad public response to Chaianov's rehabilitation. In the end, the turn towards family farming and co-operation remained an intellectual and political phenomenon with barely any impact on the agrarian order itself. The economic legacy of the Soviet era and local power constellations prevented a fundamental change of the rural order in favor of household-based agriculture.

La reconnaissance des fermes familiales et des coopératives agricoles comme catalyseurs de la relance de l'agriculture pendant la perestroïka alla de pair avec la redécouverte d'Aleksandr V. Čajanov, théoricien mondialement connu de l'économie paysanne et de son organisation. La réhabilitation de l'économiste faisait suite à l'évolution du discours public vers la fin de la période soviétique. Toutefois, le retour de Čajanov est aussi nécessairement lié à l'image officielle de l'économie rurale au cours de la décennie précédente quand, dans les débats politiques et académiques sur les exploitations auxiliaires privées, le village socialiste avait pris de nouvelles formes. L'exploitation familiale, autrefois condamnée parce que synonyme de mode de production " petit-bourgeois ", ou révélatrice d'une transition inachevée vers le socialisme, avait été acceptée comme une composante de l'agriculture socialiste. Ce changement de paradigme, qui reflétait une nouvelle conception du socialisme, constituait une condition préalable importante à la réponse du public à la réhabilitation de Čajanov. Finalement, le virage opéré vers l'exploitation familiale et les coopératives resta un épiphénomène politique et intellectuel quasiment dénué d'impact sur l'ordre agraire lui-même. L'héritage économique de la période soviétique et les pouvoirs locaux empêchèrent tout changement fondamental dans l'ordre rural en faveur d'une agriculture basée sur l'exploitation privée.

\section{AUTHOR}

\section{KATJA BRUISCH}

German Historical Institute Moscow, katja.bruisch@dhi-moskau.org 